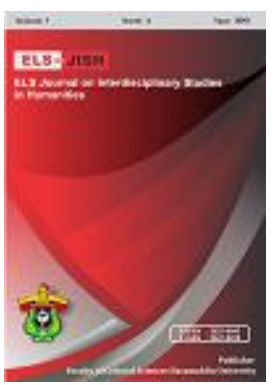

ELS-JISH

ELS Journal on Interdisciplinary Studies on Humanities

Volume 1 Issue 3, 2018

ISSN (print) : 2621-0843

ISSN (online) : 2621-0835

Homepage : http://journal.unhas.ac.id/index.php/jish

\title{
Error Analysis Found in Students' Writing Composition of Simple Future Tense
}

\author{
Tira Nur Fitria ${ }^{1}$ \\ tiranurfitria@gmail.com
}

\begin{abstract}
Error analysis is a way to investigate errors in the second or foreign language acquisition. This study of error (error analysis) is part of an investigation of the process of English language learning. This research will find the kind of error analysis found in students' writing composition in the aspects of grammar, punctuation, and spelling and to find the most dominant kind of error analysis found in students' writing composition of simple future tense. This research used the qualitative research to collect empirical data from the students' written. By using this method the data would be accurately collected. The object of the research is fifteen students' writing composition which taken from 15 students of S1 Accounting STIE AAS Surakarta. The result of analysis shows that the students' error in writing composition of simple future tense consists of three aspects of writing. First, in grammar, punctuation and spelling. In grammar aspect, there are errors in some points of class word like in noun (21 data or $36,84 \%$ ), determiner/article (2 data or 3,51\%), pronoun (1 data or 1,75\%), preposition (15 data or $26,32 \%$ ) and verb (18 data or $31,58 \%$ ), then the most dominant error in grammar aspect is noun. Second, in punctuation (16 data or 17,20\%). Third, in spelling (20 data or 21,51\%). Based on the frequency of each aspect of error writing shows that the most dominant error found in the students' writing composition is in the aspect of grammar as 57 data or 61,29.
\end{abstract}

Keywords: Error Analysis, Writing, Simple Future Tense

How to cite: Fitria, T. N. (2018). Error Analysis Found in Students' Writing Composition of Simple Future Tense. ELS Journal on Interdisciplinary Studies in Humanities, 1(3), 240-251.

\section{Introduction}

English is one kind of languages which used for communication by most of the people. It is also called as the international language which is used in every field of life. English also as the important language, because it is as the second language in this world that must be learned and mastered by everyone who wants to communicate globally. English has an important role in any aspect in life. They have to be able to speak English, be able to write, to read and to listen. Baker (2001) stated that the four basic language abilities are commonly regarded as speaking, listening, reading, and writing. As they are the four foundational skills of language learning. Listening and reading are the receptive skills because the learners do not need to produce language, but they receive and understand it. These skills are sometimes known as passive skill. The productive skills are speaking and writing because learners are applying these skills in a need to produce language. They are also known as active skills.

\footnotetext{
${ }^{1}$ College of Economics - AAS Surakarta
} 
Tira Nur Fitria. 1(3): 240 - 251

Writing is one English skill that must be mastered. In the process of teaching and learning English, writing ability is the most difficult and complicated language skill to be learned almost by the students at every level of education. Even, writing is viewed as a challenging activity for many students. In writing skill, there are many aspects to be considered. Perhaps, most students/learners do not understand it, because writing is highly-dependent on skills and competencies like spelling, outlining, and editing among others. To write clearly, it is essential to understand the basic system of a language. In English, this includes knowledge of punctuation, sentence structure and grammar,. Vocabulary is also necessary, as is correct spelling and formatting. Noguchi (1991) defines that grammar choices affect writing style, sentence combining is an effective method for helping students develop fluency and variety in their own writing style.

Writing includes numerous considerations and choices to be made regarding "higher level skills", such as content, structure and organization, and "lower level skills", such as punctuation and choice of appropriate vocabulary items and grammatical structures, which are the terms used by Richards \& Renandya (2002). Moreover, writing skill must be practiced and learned by the students/learners through experience, a language proficiency also plays a role in writing skill.

In many cases, the majority of the students are still translating words, phrases, and sentences from Indonesian to English. English learners may not have a feeling for the way that English translates into written form. (Krashen, 1982. ). The challenge for the teacher is to find the ways to activate a meaningful way the passive knowledge the students possess in terms of the writing skill, as well as to help the students become more proficient while working to eliminate some of their common errors. The learners do not realize when they commit the error because it occurs unconsciously. Therefore, teachers need to anticipate certain common types of errors. They may also find other types of errors, which can be revealed by analyzing the written products of the students. These are the conventions, which are usually followed by the teachers of writing when analyzing students' errors. Brown (2000:1) states that researchers and teacher of second languages come to realize that the mistakes a person made in this process of constructing a new system of language needed to be analyzed carefully, for the possibilities held in some of the keys to the understanding of the process of second language acquisition.

Richards (1974:1) stated that errors analysis the study and analysis of errors made by the second or foreign language learners. Based on the definition, it is known that errors analysis is necessary to conduct only for the errors made by the learners in learning second or foreign language. Error analysis is also a way to investigate errors in the second or foreign language acquisition. In this study of errors (error analysis) in students' writing composition is part of an investigation of the process of English language learning. Furthermore, from the above fact, the writer is interested in conducting the study entitled "An Error Analysis Found In Students' Writing Composition of Simple Future Tense". This research aimed to find out the kind of error analysis found in Students' Writing Composition in the aspect of grammar, punctuation and spelling and to find out the most dominant kind of error analysis found in Students' Writing Composition of Simple Future Tense. 


\section{Method}

\subsection{Research Design}

The research employed the qualitative method to collect empirical data in the form of written task for an analysis errors of the students in writing composition. The data would be directly taken from the source of the research. By using this method, the data would be accurately collected. Alwasilah (2002) defines that one of the purposes of a qualitative method or study is to acquire descriptive data. The qualitative method itself has a meaning that researched data is described through the shape of words, not in number describing. The research also employed the quantitative method. While, in this method is used to collect statistical data of verb errors collected from the written works. It was important to obtain the frequency of occurrence of the students' errors in writing composition, so that the most dominant errors or errors with high frequency can be determined.

\subsection{Data Collecting Technique}

Data collecting technique in this research is a test. The test is written tasks. Writing tasks are used to obtain and determine the students' errors in writing composition of simple future tense. In this researcher, the writer analyses the students' writing composition of Simple Future Tense. The object of the research is fifteen students' writing composition which taken from 15 students of S1 Accounting STIE AAS Surakarta during writing test.

In gathering the data for this research, the writer will do some procedures, 1) The writer prepared the instrument to test the students' errors in using simple future tense in their writing composition, 2) The writer explained the procedures in doing the written test. The writer gave the students time to do the test, 3) then the writer collected the students' writing composition to be analyzed.

\subsection{Technique of Analyzing Data}

In analyzing data in this research, the writer uses several steps, they are: 1) The writer takes the data by using a written test. The writer asks the students to write a writing composition, they are asked to write based on the same given topic.

1. After the students have finished their writing, the student's writing composition are collected and analyzed by the writer. Each of the sentences which contains of the simple future tense is put on the table and given note whether the data are correct or wrong. If the data wrong, it will be given a short description and the correction.

2. The data are identified and classified by knowing and choosing the errors that frequently appear in the student's writing composition.

3. The data are analyzed and corrected the incorrect sentences of simple future tense based on the correct grammatical of simple future tense formula. Then, the data interpretation and the conclusion can be formulated after the analysis process is completed.

4. The data are tabulated by using a statistical formula in order to find out the students' error in their writing composition. The statistical formula is being used as follows:

$P=\frac{f}{N} \times 100 \%$ 
Where: P: percentage number

$\mathrm{F}$ : frequency of error

$\mathrm{N}$ : the number of error analysis

5. Then, the data interpretation and the conclusion can be formulated after the data analysis process is completed.

\section{Findings}

The findings of this research are to answer the research objectives as formulated in the background of the study above. This research will find out the kind of error analysis found in Students' Writing Composition in the aspect of grammar, punctuation and spelling and to find out the most dominant kind of error analysis found in Students' Writing Composition of Simple Future Tense. Below the error analysis and their description of the data research as follows:

\subsection{Grammar}

Grammar is the system of a language. People sometimes describe grammar as the "rules" of a language. In the study of language, grammar occupies a central position. It is easy to learn and to use dictionaries by the learners to find the pronunciation, spelling, or meaning of words, but it is still difficult to consult grammar books without considerable knowledge of grammar. According to Greenbaum and Nelson (2002), grammar refers to the set of rules that allow us to combine words in our language into larger units. Some combinations of words are possible and others are not. He added that grammar is the central component of a language. In this research, there are some errors in grammar, especially in class word (part of speech) found in the students' writing composition. The descriptions are as follows:

\subsubsection{Noun}

For example (In the second student's composition)

Wrong: ... I want to go traveling to many destination.

Correct: ... I want to go traveling to many destinations.

From the example above shows that error of noun in student's writing. The singular countable noun 'destination' follows the quantifier 'many' which requires a plural noun. It is considered to use a plural noun or a different quantifier. It should be written 'destinations'.

For example (In the third student's composition)

Wrong: Many story and new experience on it.

Correct: Many stories and new experience on it.

From the example above shows that error of noun in student's writing. The singular countable noun 'story' follows the quantifier 'many' which requires a plural noun. It is considered to use a plural noun or a different quantifier. It should be written 'stories'.

\subsubsection{Pronoun}

For example (In the first student's composition)

Wrong: Because these three language can support to achieve my goals. 
Correct: Because this three language/these three languages can support to achieve my goals.

From the example above shows that error in student's writing. The phrase 'these three languages appears that the plural demonstrative (demonstrative pronoun). The word 'these' is modifying the singular noun 'language'. It is considered to use a singular demonstrative or a plural noun instead. It should be change into 'this three language' or 'these three languages'.

\subsubsection{Preposition}

For example (In the first student's composition)

Wrong: On next month, I will try to register in a tutoring place to learn the language.

Correct: On Next month, I will try to register in a tutoring place to learn the language.

From the example above shows that error of punctuation in student's writing. The word 'on' appears that the preposition 'on' may be unnecessary used in this context. It is considered to remove it.

For example (In the third student's composition)

Wrong: ... be a good year and bring happiness to my life.

Correct: ... be a good year and bring happiness for my life.

From the example above shows that error of punctuation in student's writing. It appears that the preposition 'to' may be incorrect in this context. It is considered to change it with the other appropriate punctuation. It should be changed into preposition 'for' in this context.

For example (In the fifth student's composition)

Wrong: so maybe I will joining a singing competition in this year.

Correct: so maybe I will joining a singing competition in this year.

From the example above shows that error of punctuation in student's writing. It appears that the preposition 'in' may be unnecessary used in this context. It is considered to remove it.

\subsubsection{Verb}

For example (In the first student's composition)

Wrong: If I am accept in a tutoring place, I will try to learn the lesson that has been delivered.

Correct: If I am accepted in a tutoring place, I will try to learn the lesson that has been delivered.

From the example above shows that error of verb in student's writing. It appears that the form of the verb 'accept' does not work with to be 'am' in this sentence. The word 'accept' should be changed into 'accepted' to form a passive voice with formula $\mathrm{S}+$ To be (is/am/are) + V3 (past participle). Therefore, it should be written 'I am accepted'.

For example (In the fourth student's composition)

Wrong: My dream in 2018 are, I will pass my study faster, and I shall buy many thing 
Tira Nur Fitria. 1(3): 240 - 251

Correct: My dream in 2018 is, I will pass my study faster, and I shall buy many thing

From the example above shows that error of the verb (to be) in student's writing. The verb 'are' does not seem to agree with the subject (noun phrase) 'My dream'. It is considered to change the verb form (to be) plural 'are' into singular 'is'.

For example (In the first student's composition)

Wrong:..., so maybe I will joining a singing competition in this year.

Correct: ..., so maybe I will joining a singing competition in this year.

From the example above shows that error of verb in student's writing. It appears that in the sentence or clause uses an incorrect form of the verb 'joining'. It is considered to delete the 'ing' in Ving, or it follows the rule of simple future tense $S+$ will + V1. Therefore, the correct is 'join'.

\subsubsection{Determiner/Article}

For example (In the fourth student's composition)

Wrong: I have resolution for my better life.

Correct: I have a resolution/ the resolution for my better life.

From the example above shows that error of determiner/article in student's writing. The noun phrase 'resolution' seems to be missing a determiner before it. It is considered to add an article 'a' or 'the'. It should be 'a resolution' or 'the resolution'.

For example (In the fourth student's composition)

Wrong:... and then I will get better job.

Correct: ... and then I will get a better/ the better job.

From the example above shows that error of determiner/article in student's writing. The noun phrase 'better job' seems to be missing a determiner before it. It is considered to add an article 'a' or 'the'. It should be 'a better' or 'the better'.

For example (In the first student's composition)

Wrong: In the beginning of 2018, everyone must be wish for the best life.

Correct: At the beginning of 2018, everyone must be wish for the best life.

From the example above shows that error of determiner/article in student's writing. The preposition 'in' may be incorrect in this context. It is considered to change it to a different preposition. It should be changed into preposition ' $a$ '.

For example (In the first student's composition)

Wrong: ... the beauty of afternoon on the beach.

Correct: ... the beauty of the afternoon on the beach.

From the example above shows that error of determiner/article in student's writing. It appears that an article is missing before the word 'afternoon'. It is considered to add an appropriate article 'the'. Then, it will be 'the afternoon'.

\subsection{Punctuation}

Punctuation is the symbols that are used to aid the clarity and comprehension of written language. Some common punctuation marks are the period, comma, 
question mark, exclamation point, apostrophe, quotation mark and hyphen. Punctuation has the function to indicate where pauses, stops, questions, omissions, introductions, and other forms of expression occur in the writing. In this research, there are some errors in punctuation found in the students' writing composition. The descriptions are as follows:

For example (In the first student's composition)

Wrong: Hopefully I will be success with my resolution.

Correct: Hopefully, I will be success with my resolution.

From the example above shows that error of punctuation in student's writing. It appears that there is missing a comma after the introductory phrase 'Hopefully'. It is considered to add a comma after it. It should be 'Hopefully,'

For example (In the first student's composition)

Wrong: I can go abroad, if I have a lot of money.

Correct: I can go abroad if I have a lot of money.

From the example above shows that error of punctuation in student's writing. It appears that in the word 'abroad' have an unnecessary comma before the dependent clause marker 'if'. It is considered to remove the comma. It should be 'abroad'.

For example (In the first student's composition)

Wrong: In addition I want to try to find a part time job.

Correct: In addition, I want to try to find a part time job.

From the example above shows that error of punctuation in student's writing. It appears that there is missing a comma after the introductory phrase 'In addition'. It is considered to add a comma after it. It should be 'In addition,'

For example (In the first student's composition)

Wrong: For my study I wish I get sore high.

Correct: For my study, I wish I get sore high.

From the example above shows that error of punctuation in student's writing. It appears that there is missing a comma after the introductory phrase 'For my study. It is considered to add a comma after it. It should be 'For my study,'

For example (In the first student's composition)

Wrong: Hello my name is Nanda, I'm 20 years old.

Correct: Hello my name is Nanda, I'm 20 years old.

From the example above shows that error of punctuation in student's writing. It appears that there is a missing a punctuation mark after the interjection 'Hello'. It is considered to add a comma after it. It should be 'Hello,'.

\subsection{Spelling}

Spelling is an aspect of written language, therefore the teaching and learning of spelling must take place as far as possible within the context of writing (Croft (1983:9). It means that spelling has its rules to form the words correctly. Letters must appear in a correct sequence to be meaningful. In this research, there are some 
Tira Nur Fitria. 1(3): 240 - 251

errors in spelling which is found in the students' writing composition. The descriptions are as follows:

For example (In the first student's composition)

Wrong: I will go to enjoy the beautiful scenary in the mountains.

Correct: I will go to enjoy the beautiful scenery in the mountains.

From the example above shows that error of spelling in student's writing. The word 'scenary' is not in the dictionary. Maybe the spelling is not correct. It can use dictionary to prevent future alerts. The error word 'scenary' can be replaced by the word 'scenery' which the meaning has correlation with the context.

For example (In the first student's composition)

Wrong: I will be business man as I want. If I was being with my family at home.

Correct: I will be businessman as I want. If I was being with my family at home.

From the example above shows that error of spelling in student's writing. The word 'business man' seems to be miswritten in this context. It is considered to replace it with other words' or change a space between 'business' and 'man' to make appropriate meaning in this context.

For example (In the first student's composition)

Wrong: I pray for my dream and my family to be granted by the omnipresent god.

Correct: I pray for my dream and my family to be granted by the omnipresent God.

From the example above shows that error of spelling in student's writing. It appears that the word 'god' may be a proper noun in this context. It is considered to capitalize the word into 'God'.

For example (In the seventh student's composition)

Wrong: It's too privacy to share my financial.

Correct: It's too private to share my financial.

From the example above shows that error of spelling in student's writing.

From the example above shows that error of spelling in student's writing. It is related to the diction used in this context. The word 'privacy' does not seem to fit in this context. It is considered to replace the error word with a different one. It should be changed into 'private' to make appropriate meaning in this context.

For example (In the fifth student's composition)

Wrong: I wish also fast graduate with cum laude score and get a good work.

Correct: I wish also fast graduate with cum laude score and get a good work.

From the example above shows that error of spelling in student's writing. It is related to the diction used in this context. The word 'cumlaude' does not seem to fit in this context. It is considered to replace the error word with a different form. It can be added a space between 'cum' and 'laude' to make appropriate meaning in his context into 'cum laude'. Then, the word 'cum laude' refers to an academic honor given to a graduate.

For example (In the seventh student's composition) 
Wrong: I want to take responsibility about my own life.

Correct: I want to take responsibility about my own life.

From the example above shows that error of spelling in student's writing. The word 'responsibility' is not in the dictionary. Maybe the spelling is not correct. It can use dictionary to prevent future alerts. This error also relates to the diction used in this context. The word 'responsibility' does not seem to fit in this context. It is considered to replace the error word with a different one. It should be changed into 'responsibility' to make appropriate meaning in this context.

\section{Discussion}

In language learning, an error that learners make in their writing is caused by they do not know the syntactic as well. Ellis (1997) explained that errors reflect gaps in the learner's knowledge, it is an error which is produced due to the fact that the learners can identify what is correct and incorrect. According to Tarigan (1988), the error is caused by competence factors. It means that the students do not really understand the system of language linguistic. Usually, an error occurs consistently and systematically. Errors are sometimes classified according to vocabulary (lexical error), pronunciation (phonological error) and grammar (syntax error), misunderstanding of a speaker's intention or meaning (interpretive error), production of the wrong communicative effect through the faulty use of a speech act or one of the rules of speaking (pragmatic error). Norrish (1983: 7) states that error is a systematic deviation when a learner has not learnt anything an consistently get it wrong. In acquiring his own language sometimes a child consistently makes the same errors. In the same way, when a learner of English as a second language or foreign language makes an error systematically because he has not learnt the correct form.

Error analysis is the study and analysis of the errors made by second and foreign language. According to Brown (2000), the fact that learners do make errors and that these errors can be observed, analyzed, and classified to reveal something of the system operating within the learner, led to a surge of study of learners" error, called error analysis. Furthermore, people can observe something, analyze the data that we could get from the observation and make the classification of them.

This research will find out the kind of error analysis found in the Students' Writing Composition in the aspect of grammar, punctuation and spelling and to find out the most dominant kind of error analysis found in Students' Writing Composition of Simple Future Tense. Below the table of the result of students' writing composition, it is found of errors in the aspect of grammar, punctuation and spelling.

\subsection{Table Frequency of Error in Students' Writing Composition}

\begin{tabular}{|c|c|c|c|c|c|c|c|}
\hline \multirow{4}{*}{ ASPECT } & \multicolumn{7}{|c|}{ Error } \\
\hline & \multicolumn{5}{|c|}{ GRAMMAR } & \multirow[t]{2}{*}{ PUNCTUATION } & \multirow[t]{2}{*}{ SPELLING } \\
\hline & Noun & $\begin{array}{l}\text { Determiner } \\
\text { /Article }\end{array}$ & Pronoun & Preposition & Verb & & \\
\hline & $\begin{array}{c}21 \\
36,84 \\
\%\end{array}$ & $\begin{array}{c}2 \\
3,51 \%\end{array}$ & $\begin{array}{c}1 \\
1,75 \%\end{array}$ & $\begin{array}{c}15 \\
26,32 \%\end{array}$ & $\begin{array}{c}18 \\
31,58\end{array}$ & & \\
\hline TOTAL & & & 57 & & & 16 & 20 \\
\hline$\%$ & & & $61.29 \%$ & & & $17,20 \%$ & 21,51 \\
\hline
\end{tabular}

From the table above, it shows that the students' error in writing composition of simple future tense consists of three aspects of writing. First, in grammar, 
Tira Nur Fitria. 1(3): 240 - 251

punctuation and spelling. In grammar aspect, there are errors in some points of class word like in noun (21 data or 36,84 \%), determiner/article (2 data or 3,51\%), pronoun ( 1 data or $1,75 \%$ ), preposition (15 data or $26,32 \%$ ) and verb (18 data or $31,58 \%$ ), then the most dominant error in grammar aspect is noun. Second, in punctuation (16 data or $17,20 \%$ ). Third, in spelling (20 data or $21,51 \%$ ). Based on the frequency of each aspect of error writing shows that the most dominant error found in the students' writing composition is in the aspect of grammar as 57 data or 61,29 . Below the analysis and description of the students' error in writing composition of simple future tense consist of three aspects of writing, as follows:

First, in aspect of grammar. In linguistics, grammar is the set of structural rules which influences the composition of clauses, phrases, and words in any given language. It is the systematic study and a description of a language, and it helps people to understand how words and their component parts combine to form sentences. Basically, if the learners want to be able to speak or write English well, they have to master the rule of English it called "grammar". English has a lot of rules to be noticed and learnt. It seems that one of the causes errors often appears because most learners do not understand grammar. Learning process of English as second language, error commonly happens systematically. It is because the learners cannot understand the form. In analysing the reason why error often occurs, it is important to notice the distinction between teaching and learning.

In this research, there are some errors of noun in students' writing composition. Most of them still write errors in writing noun phrase. A noun phrase is a group of words that work together to name and describe a person, place, thing, or idea. A noun phrase has two parts: a noun, and any modifiers connected to that noun. These modifiers will be adjectives, articles, and prepositional phrases. The modifiers may also be determiners. There are only three articles in modern English: a, an, the. An article is always connected to a noun, and so when one is used, it is always part of a noun phrase. Based on the example of the data, it still found that the students write error in noun phrase which does not follow the formula of a noun phrase (Article/Determiner + Noun).

Second, in aspect of punctuation. Punctuation is the use of special marks in writing. Punctuation as the system of signs or symbols given to the readers to show how a sentence is constructed and how it should be read. Punctuation shows how the sentence should be read. Punctuation also makes the meaning clear. Using punctuation is very important because it can make the reader easily understand the meaning in. The functions of punctuation marks are to separate words and phrases within a sentence according to their meanings. Misused of punctuation, for instance, a question mark (?), instead of a full stop (.), at the end of a sentence may convey a different meaning (Bram, 1995). In this research, there are some errors of noun in students' writing composition. Most of them still write errors in writing punctuation especially in comma. Commas show a minor break or pause in a sentence (Langan, 2006). Using a proper comma makes the meaning of sentences clear by grouping and separating words, phrases, and clauses. Based on the data example above, it shows that there are missing a comma after the introductory phrase in the beginning of the sentence. It is considered to add a comma after it.

Third, in aspect of spelling. Spelling error usually occurs because the students cannot distinguish between letters and sound of the words when they write. According to Peveen and Akram (2014:2605), aspect like sounds, letters, word parts, 
word meaning, and word history are those elements which play the important role in learning to spell the words of the English language. In addition, a single sound (more correctly, a single phoneme) may have many different spellings and the same spelling may have many different sounds (word, information, worry, correspond) (Harmer, 2000:256). In this research, there are some errors of spelling in students' writing composition. Based on the data example above, it shows that some words are not found in the dictionary. It can use dictionary to prevent future alerts. These errors maybe the spelling is not correct or the word is miswritten in its letter both vocal or consonant in the context, or it is considered to replace it with other words with appropriate with the context.

\section{Conclusion}

In writing, some aspects like grammar, punctuation and spelling skills really helps the learners/students to communicate clearly. Grammar is related to using words, according to set conventions and rules. An understanding of the 8 key grammatical terms is essential in all written communication. These are: noun, pronoun, verb, determiner/article, adverb, adjective, preposition, and conjunction. Punctuation is related with marking off, by means of certain conventional signs, the divisions of a sentence so as to bring out the meaning more clearly. The 9 most frequently met signs are: full stops; commas; semi-colons; colons; apostrophes; quotation marks; brackets; and interrogation and exclamation marks. While, spelling is, quite simply, the correct sequence of letters for words. English has a lot of rules to be noticed and learnt. It seems that one of the causes errors often appears because most learners do not understand the aspect. Learning process of English as second language, error commonly happens systematically.

The result analysis shows that the students' error in writing composition of simple future tense consists of three aspects of writing. First, in grammar, punctuation and spelling. In grammar aspect, there are errors in some points of class word like in noun (21 data or 36,84 \%), determiner/article (2 data or 3,51\%), pronoun ( 1 data or $1,75 \%$ ), preposition (15 data or $26,32 \%$ ) and verb (18 data or $31,58 \%$ ), then the most dominant error in grammar aspect is noun. Second, in punctuation (16 data or $17,20 \%$ ). Third, in spelling (20 data or $21,51 \%$ ). Based on the frequency of each aspect of error writing shows that the most dominant error found in the students' writing composition is in the aspect of grammar as 57 data or 61,29.

\section{Reerences}

Alwasilah, A. Chaedar. (2002). Pokoknya Kualitatif. Jakarta: Pustaka Jaya.

Baker, C. (2001). Foundation of Bilingual Education and Bilingualism (3rd ed.). Clevedon, UK: Multilingual Matters.

Bram, B. (1995). Write Well (Improving Writing Skills. Yogyakarta: Kanisius.

Brown, H.D. (2000). Principles of Language Learning and Teaching. New York: Longman.

Croft, Cedric. (1983). Teacher Manual for Spell-Write an Aid to Writing, Wpelling and Word Study. New Zealand: Council for Educational Research Wellington.

Ellis, R. (1997). Second Language Acquisition. New York: Oxford University Press.

Ellis, R. (2008). The Study of Second Language Acquisition. Oxford, UK: Oxford University Press. 
Tira Nur Fitria. 1(3): 240 - 251

Greenbaum, S \& Nelson, G. (2002). An Introduction to English Grammar (Second ed.). Essex: Longman

Halliday, M.A.K. (2002). On Grammar. London: Peking University Press.

Harmer, J. (2000). How to Teach English an Introduction to Practice of English Language Teaching. Longman: England.

Harmer, Jeremy. (1983). The Practice of English Language Teaching. London: Longman Group.

Krashen, S. (1982). Principles and Practices in Second Language Acquisition. Oxford. Pergamon Press.

Langan, J. (2006). English Skill with Reading. England: The McGraw-Hill.

Noguchi, R. R. (1991). Grammar and the Teaching of Writing: Limits and Possibilities. Urbana, IL: National Council of Teachers of English.

Norrish, J. (1983). Laguage Learners and Their Errors. London: Macmillan Press.

Perveen, U. \& Akram, F. (2014). A Comparative Study to know the causes of Spelling Errors Committed by Learners of English at Elementary Level in Distract Kasur and Lahore in Pakistan. European Academic Research, 2(2): 2601-2622.

Richard. Jack. (1974). Error Analysis Prospective on Eighth Language Acquisition. London: Longman.

Richards, J. C. \& Renandya, W. A. (eds) (2002) Methodology in Language Teaching: An Anthology of Current Practice. Cambridge: Cambridge University Press.

Tarigan, Henry Guntur. (1988). Pengajar Analisis Kesalahan. Bandung: Angkasa 